\title{
A CÂMARA MUNICIPAL DE CURITIBA E O LABOR LEGISLATIVO: AS INTERFACES DA REPRESENTAÇÃO POLÍTICA, de Antonio Carlos Torrens ${ }^{1}$
}

\author{
Mônica Helena Harrich Silva Goulart ${ }^{2}$
}

- Enviado em 30/01/2016

- Aprovado em 24/02/2016

Defendida pelo Programa de Pós-Graduação em Sociologia da Universidade Federal do Paraná, em 2015, a tese de Antonio C. Torrens, A Câmara Municipal de Curitiba e o Labor Legislativo: as interfaces da representação política, sob a orientação do prof. Dr. Ricardo Costa de Oliveira, torna-se mais uma contribuição importante para os estudos desenvolvidos no NEP Núcleo de Estudos Paranaenses.

Tema pertinente para o conhecimento de nossas instituições representativas, a análise de Torrens tem o objetivo de compreender a prática política e institucional da Câmara Municipal de Curitiba no período específico entre 2008 a 2013, embora não delimite a análise neste contexto. O direcionamento do estudo se estabelece na verificação das atividades legislativas e nas atividades de fiscalização, intrínsecas às funções do poder legislativo. Numa perspectiva ampla, busca-se compreender a conexão estabelecida entre representantes e representados através da problematização e análise dos projetos de lei, requerimentos, indicações, homenagens, pedidos de informação e resoluções praticados pelos vereadores, no contexto definido pelo autor.

Na construção de tal análise, Torrens subdivide o texto em quatro partes: Cap. 1 - Balanço bibliográfico sobre a representação política e parlamentar; Cap. 2 - A Câmara Municipal de

\footnotetext{
${ }^{1}$ Tese de autoria de Antônio Carlos Torrens, defendida no Programa de Pós-Graduação em Sociologia da UFPR, na linha Sociedade e Estado, em 2015, sob orientação do Prof. Dr. Ricardo Costa de Oliveira. Versão completa disponível na Biblioteca Digital da UFPR - http://dspace.c3sl.ufpr.br:8080/dspace/bitstream/handle/1884/40821/R\%20-\%20T\%20$\%$ 20ANTONIO\%20CARLOS\%20TORRENS.pdf?sequence=1\&isAllowed $=\mathrm{y}$.

${ }^{2}$ Professora Adjunta do Departamento Acadêmico de Estudos Sociais (DAESO), Universidade Tecnológica Federal do Paraná - UTFPR. Pós-doutoranda em Sociologia na Universidade Federal do Paraná. Endereço eletrônico: mharrich@uol.com.br/mhasilva@utfpr.edu.br.
} 
Curitiba: trajetória de um poder; Cap. 3 - O Município e a Organização Político-Administrativa Local: a Câmara Municipal de Curitiba e as mudanças recentes; Cap. 4 - A construção das conexões político-representativas no parlamento municipal: a ação que excede e a ação que carece.

Ao estruturar teoricamente sua pesquisa, lança mão da discussão neoinstitucionalista e apresenta as mudanças de enfoque em relação aos estudos do legislativo que ocorrem desde a década de 1980. Assim, apresenta concomitantemente discussão sobre democracia, representação política, sobre o presidencialismo e a relação legislativo/executivo, além de desenvolver análise sobre o pluralismo político.

Nesse sentido, a busca teórica se estabelece na medida em que a preocupação de Torrens se coloca em averiguar a melhor forma de representação política, mais precisamente, questiona o mecanismo atual de representação na Câmara Municipal de Curitiba se converte em qualidade representativa. Em outros termos, avalia até que ponto a população tem, de fato, voz política em termos de intervenção "nas grandes decisões políticas e sociais". Então, quais seriam os expedientes que interferem negativamente na atividade legislativa? Para Torrens, a interferência cada vez mais presente do "poder judiciário como árbitro de questões políticas", assim como a transferência para os tribunais de resoluções que caberiam tão somente às esferas do legislativo e do executivo. As questões em torno das políticas públicas no âmbito municipal também se tornam aspectos de reflexão do autor.

Para pensar na realidade curitibana, Torrens lança mão dos aspectos históricos de criação da Câmara Municipal de Curitiba no ano de 1693 e percorre, pontualmente, as alterações ocorridas em tal locus de poder. No contexto atual, as transformações decorrentes da CF de 88 são também destacadas pelo autor na medida em que apresenta, por exemplo, a primeira lei de iniciativa popular criada na CMC, que foi aprovada somente em 2013, dispondo sobre "a publicidade e transparência das atribuições, objetivos, gastos e orçamento dos Conselhos de Políticas Públicas Municipais" (apresentada por pessoa jurídica de direito privado - Centro Acadêmico de Direito Sobral Pinto, do Curso de Direito da PUCPR). O pesquisador também destaca outras formas de participação direta da população como as audiências e consultas públicas, o Conselho das Cidades e o Plano Diretor.

Os mecanismos de controle interno e externo são também elencados por Torrens. Nesse caso, o destaque se dá a partir do caso da CPI da Publicidade, instalada em 2011, para averiguar irregularidades quanto ao uso de verbas para a publicidade. Como resultado da investigação, o então presidente da Casa, Francisco Derosso (membro de família tradicional da política paranaense), perdeu seu cargo de presidente porque pediu afastamento, mas a perda do mandato de vereador se deu por infidelidade partidária e não pelo seu envolvimento em corrupção. A empresa Oficina da Notícia (à época, propriedade de sua esposa, Claudia Queiroz) recebeu mais de 5,1 milhões pelo 
contrato de publicidade, ao qual não foi cumprido. Porém, o TC do Paraná apontou valores maiores e também o envolvimento de outros vereadores.

Em relação à avaliação do desempenho das atividades legislativas desenvolvidas na CMC, identifica-se que os atores políticos, em meio a precária participação da população dentro dos aspectos legais permitidos (decorrentes, muitas vezes pelas dificuldades burocráticas que são impostas), têm dificuldades para realizar suas funções básicas ao assumirem atividades que não são relevantes para o interesse da sociedade curitibana. Para o autor, um dos pontos mais nevrálgicos na atuação da vereança está na elaboração de políticas públicas sintetizadas na Lei Orçamentária Anual que, de forma resumida, continuam sendo elaboradas, predominantemente, pelo poder executivo. Nesse enfoque da pesquisa, o exame da dinâmica partidária e as coalizões realizadas, o perfil dos vereadores e as atividades desenvolvidas pelos mesmos, além da delimitação das áreas de atuação no município se fazem presentes de forma pormenorizada.

Enfim, a análise desenvolvida compreende um olhar que vai além do posicionamento objetivo do pesquisador, pois Torrens permeia o cotidiano da casa legislativa (também como servidor municipal) através do detalhamento das atividades realizadas pelos parlamentares, assim como também aponta com precisão as inúmeras lacunas e inversões realizadas em suas atuações, desviando, muitas vezes, de seus propósitos mais básicos, qual seja, a legislação direcionada para o espaço local e a fiscalização perante outros poderes que também interferem no referido contexto.

Portanto, a presente tese se coloca como significativa indicação para estudiosos do legislativo em geral e de esferas específicas de poder, como também para aqueles que se debruçam a respeito da dinâmica, tarefas e ações dos representantes do legislativo de Curitiba, haja vista os apontamentos realizados em relação aos vereadores que compõem o referido período. Além de leituras possíveis pelo viés da História, da Sociologia Política, do Direito e da Ciência Política. 